\title{
Eksistensi Perbankan Syariah di Indonesia
}

\author{
Imroatus Sholiha*
}

\begin{abstract}
This article aims to find out the existence of Islamic banking in Indonesia, This research uses qualitative descriptive research method. In this descriptive qualitative research, the researcher uses literature study which is searching information through books, magazines, journals, SPS OJK date, reference books, and other sources either in written form or in relevant digital format and related to research study object. The results of this study show that sharia banking first started to enter Indonesia in 1992 pioneered by Bank Muamalat Indonesia (BMI) until now its existence still exist and develop rapidly. Visible from year to year the number of sharia banking office experienced a rapid growth yaitu increasing number of offices spread throughout the province in Indonesia both Sharia (BUS), Syariah Business Unit (UUS) and BPRS. For the branch network of BUS and UUS in 2016 for KPO / KC as much as 623, KCP/UPS as many as 1,342 and KK as many as 240. While the number of BPRS in Iindonesia in 2012 as many as 158 and increased in 2016 to 166. So is the number of customers who save money and take the number of pembisiyaan increasingly increasing year in 2014 the number of customers BUS Dan UUS as much as 11,444,013 and increased in 2016 to 18. 521.121. As for the number of accounts both DPK and Financing also increased from year to year. For the DPK of 2014 the number is 14,386,575 and increased in 2016 to 22. 198.718, and for financing, receivables and greetings in the year 2014 amounted to 3. 769,181 in 2016 increased to 4,515,930.
\end{abstract}

Keywords: existence, Islamic banking, Indonesia

* Dosen Tetap IAI Ibrahimy Sukorejo Sumberejo Banyuputih Situbondo 


\section{A. Pendahuluan}

Dalam era modern ini keberadaan bank menjadi kebutuhan bagi semua elemen masyarakat baik masyarakat kota maupun yang berada di pedesaan. Bank adalah lembaga keuangan atau badan usaha yang menghimpun dana dari masyarakat yang memiliki surplus dana dalam bentuk simpanan dan menyalurkannya kepada masyarakat yang deficit dana atau masyarakat yang membutuhkan dana dalam bentuk kredit dan atau bentuk-bentuk lainnya dalam rangka meningkatkan taraf hidup masyarakat. Keberadaan perbankan sangat dibutuhkan oleh semua elemen masyarakat terlebih lagi masyarakat yang sudah memiliki pemikiran yang maju dan sudah tidak sedikit masyarakat yang mengerti tentang teknologi, yang memposisikan bank sebagai kebutuhan yang tidak bisa dipandang sebelah mata. Semakin maraknya dan gencarnya transaksi yang mengharuskan masyarakat menggunakan jasa perbankan, membuat perbankan harus tetap berusaha memberikan pelayanan yang terbaik untuk masyarakat secara luas. Sehingga masyarakat tidak perlu khawatir dan merasa kebingungan dikala mereka membutuhkan dana maupun dikala mereka kelebihan dana. Ketika mereka kelebihan dana untuk rasa keamanan mereka bisa menyimpan uangnya di perbankan, dan jika mereka mengalami deficit atau membutuhkan modal mereka bisa mengajukan pembiayaan ke perbankan. Dan untuk kebutuhan lainnya perbankan juga menyediakan beberapa jasa yang mempermudah terhadap pemenuhan kebutuhan masyarakat semisal melayani transfer, melihat saat ini kebanyakan tratnsaksi menggunakan online dan masih banyak lagi keunggulan dan kegunaaan dengan adanya perbankan ini.

Namun yang menjadi kendala mengapa masyarakat masih kurang percaya dengan adanya perbankan salah satunya adalah karena adanya sistem bunga yang biasa diterapkan di perbankan konvensional. Hal itu dirasa memberatkan bagi nasabah yang ingin mengambil pembiayaan dengan harus membayar bunga yang sudah ditetapkan di awal. Kehadiran perbankan syariah merupakan solusi atas kegelisahan nasabah akan adanya bunga yang diterapkan oleh perbankan konvensional. Perbankan syariah hadir dengan sistem bagi hasilnya. Apabila masyarakat ingin mengambil pembiyaan maka perbankan syariah tidak mengenakan bunga melainkan menerapkan sistem bagi hasil yang apabila mendapat keuntungan atas kerjasama tersebut maka akan dirasakan bersama begitu juga sebaliknya.

Bank syariah merupakan bank yang kegitannya mengacu pada hukum islam dan dalam kegitannya tidak membebankan bunga maupun tidak membayar bunga kepada nasabah. Undang-undang perbankan syariah no. 21 tahun 2008 menyatakan bahwa perbankan syariah adalah segala sesuatu yang menyangkut bank syariah dan unit usaha syariah, mencakup lembaga, kegiatan usaha, serta cara dan proses dalam pelaksanaan kegiatan usahanya. Bank syariah adalah bank yang menjalankan kegiatannya berdasarkan prinsip syariah dan menurut jenisnya terdiri dari Bank Umum Syariah (BUS), usaha unit syariah (UUS), dan Bank Pembiayaan Rakyat Syariah (BPRS). ${ }^{1}$

${ }^{1}$ Ismail, Perbankan Syariah, (Jakarta : Kencana-Prenada Media Group, 2011), 31-32 
Bank umum syariah (BUS) adalah bank yang berdiri sendiri sesuai dengan akta pendiriannya, bukan merupakan bagian dari bank konvensional. Bank unit usaha syariah merupakan unit usaha syariah yang masih dibawah pengelolaan bank konvensional. Unit usaha syariah adalah unit kerja dari kantor pusat bank konvensional yang berfungsi sebagai kantor induk dari kantor atau unit yang melaksanakan kegiatan usaha berdasarkan prinsip syariah, atau unit kerja dikantor cabang dari suatu bank yang berkedudukan di luar negeri yang melaksanakan kegiatan secara konvensional yang berfungsi sebagai kantor induk dari kantor cabang pembantu syariah atau unit usaha syariah. $^{2}$

Yang menjadi pertanyaan saat ini adalah kenapa harus ada perbankan diseluruh lapisan masyarakat baik kota besar maupun dikota-kota kecil, lebih-lebih perbankan syariah?. Dari beberapa hasil penelitian menunjukkan bahwa lembaga keuangan bank maupun non-bank yang bersifat formal dan beroperasi di pedesaan, umumnya tidak dapat menjangkau lapisan masyarakat dari golongan ekonomi menengah ke bawah. Ketidakmampuan tersebut terutama dalam sisi penanggungan resiko dan biaya operasi, juga dalam identifikasi usaha dan pemantauan penggunaan kredit yang layak usaha. Ketidakmampuan lembaga keuangan ini menjadi penyebab terjadinya kekosongan pada segmen pasar keuangan di wilayah pedesaan. Akibatnya 70\% s/d 90\% kekosongan ini diisi oleh lembaga keuangan non formal, termasuk yang ikut beroperasi adalah para rentenir dengan mengenakan suku bunga yang tinggi. Untuk menanggulangi kejadiankejadian seperti ini perlu adanya suatu lembaga yang mampu menjadi jalan tengah. Wujud nyatanya adalah dengan memperbanyak mengoperasionalkan lembaga keuangan berprinsip bagi hasil, yaitu : Bank Umum Syariah, BPR Syariah dan Baitul Maal Wat Tamwil. $^{3}$

Namun untuk saat ini sudah banyak perbankan syariah mulai dari BMT, BPRS, bahkan BSM dan BMI yang sudah mulai membuka cabang di beberapa kecamatan dan bisa melayani masyarakat desa. Dan hebatnya lagi lebel syariah juga bisa memberikan atau menularkan sistem syariahnya kepada bank-bank konvensional yang awalnya operasional mereka menggunakan sistem konvensional akan tetapi saat ini tidak sedikit bank konvensional yang sudah membuka unit yang berlebelkan syariah. Banyaknya bank konvensional yang membuka unit syariah ini membuktikan bahwa sistem yang diterapkan oleh perbankan syariah ini bisa diterima oleh banyak kalangan baik dari praktisi perbankan maupun masyarakat. Banyaknya masyarakat yang mulai melirik terhadap perbankan yang berbasis syariah menuntut bank konvensional juga membuka unit bank syariah guna memfasilitasi kebutuhan masyarakat yang sudah bisa menikmati sistem berbasis syariah. Tidak bisa dipungkiri Bank syariah di Indonesia lahir setelah banyaknya bank konvensional di Indonesia. Akan tetapi bank syariah bisa menunjukkan kekuatannya pada Indonesia bahkan kepada dunia ketika terjadi krisis moneter pada kisaran tahun 1997, bank syariah yang bisa dikatakan bank baru, bisa menghadapi krisis moneter tersebut dengan sistem bagi hasilnya sehingga mereka tidak pailit dan tetap

2 Ibid, 32

3 Muhammad, Manajemen Bank Syariah, (Yogyakarta : UPP AMP YKPN, 2002), 16 
eksis sampai saat ini. Dan hingga hari ini Bank syariah masih dipercaya dan dibutuhkan masyarakat, meskipun ada juga masyarakat yang kurang minat terhadap bank syariah akan tetapi juga tidak sedikit yang sangat berminat pada bank syariah dan bukti nyatanya adalah dengan bertambah banyaknya bank syariah yang masuk di lingkungan kota kecil bahkan kecamatan. Maka dari itu salah satu tujuan dari tulisan ini adalah untuk mengetahui bagaimana eksistensi bank syariah hingga bisa bertahan dan berkembang sampai saat ini.

\section{RUMUSAN MASALAH}

Berdasarkan pendahuluan di atas, artikel ini bermaksud ingin mengungkapkan bagaimana eksistensi perbankan syariah yang ada di Indonesia. 


\section{B. Metodologi Penelitian}

Penelitian ini merupakan penelitian deskriptif kualitatif. Tujuan penelitian ini adalah menafsirkan dan menuturkan data yang bersangkutan dengan situasi yang sedang terjadi, sikap/pandangan yang terjadi di dalam masyarakat, pertentangan 2 keadaan atau lebih, pengaruh terhadap suatu kondisi dan lain sebagainya. Sedangkan studi kepustakaan menurut Nazir ${ }^{4}$ adalah teknik pengumpulan data dengan mengadakan studi penelaahan terhadap buku-buku, literatur-literatur, catatan-catatan, dan laporan-laporan yang ada hubungannya dengan masalah yang dipecahkan. Penelitian ini juga untuk menelaah sumber-sumber tertulis seperti jurnal ilmiah, buku referensi, literature, dan lain sebagainya yang berhubungan dengan obyek penelitian. Adapun obyek kajian dalam penelitian ini adalah eksistensi perbankan syariah yang ada di Indonesia baik dari jumlah perbankan syariah saat ini, dan DPK serta pembiayaan yang disalurkan oleh perbankan syariah.

\section{Pembahasan}

\section{Pengertian bank syariah}

Bank Islam atau selanjutnya disebut dengan bank syariah adalah bank yang beroperasi tidak mengandalkan pada bunga. Bank Islam atau biasa disebut dengan bank tanpa bunga adalah lembaga keuangan/perbankan yang operasional dan produknya dikembangkan berlandaskan pada Al-qur'an dan hadist Nabi SAW. Atau dengan kata lain, Bank Islam adalah lembaga keuangan yang usaha pokoknya memberikan pembiayaan dan jasa-jasa lainnya dalam lalu lintas pembayaran serta peredaran uang yang pengoperasiannya disesuaikan dengan prinsip syariat Islam. ${ }^{5}$

Bank syariah adalah suatu bank yang dalam aktivitasnya baik dalam penghimpunan dana maupun dalam rangka penyaluran dananya memberikan dan mengenakan imbalan atas dasar prinsip syariah. Bank syari'ah adalah bank yang beroperasi dengan tidak mengandalkan operasionalisisnya pada bunga. Bank Islam atau biasa disebut dengan Bank tanpa bunga, adalah lembaga keuangan/perbankan yang operasional dan produknya dikembangkan berlandaskan pada Al Qur'an dan Hadits Nabi SAW. Dengan kata lain, Bank Islam adalah lembaga keuangan yang usaha pokoknya memberikan pembiayaan dan jasa-jasa lainnya dalam lalu lintas pembayaran serta peredaran uang yang pengoperasiannya disesuaikan dengan prinsip syari'at Islam. ${ }^{6}$

\section{Sejarah perbankan syariah di Indonesia}

Berkembangnya bank -bank syariah di Negara-negara Islam berpengaruh ke Indonesia. Pada awal periode 1980-an diskusi mengenai bank syariah sebagai pilar ekonomi Islam mulai dilakukan. Para tokoh yang terlibat dalam kajian tersebut adalah Karnaen A. Perwataatmadja, M. Dawam Rahardjo, A.M. Saefuddin, M.

4 M. Nazir, Metode Penelitian, cet, ke 5 (Jakarta : Ghalia Indonesia, 2003), 27

5 Opcit, Muhammad, Manajemen Bank Syariah, 13

6 Machmud Amir \& Rukmana, Bank Syariah, (Jakarta : Erlangga, 2010), 23 
Amien Azis, dan lain-lain. Beberapa uji coba pada skala yang relative terbatas telah diwujudkan. Diantaranya adalah Baitul Maal Wat tamwil-Salman Bandung yang sempat tumbuh mengesankan. Di Jakarta juga dibentuk lembaga serupa dalam bentuk koperasi, yakni koperasi Ridho Gusti.

Akan tetapi prakarsa lebih khusus untuk mendirikan bank Islam di Indonesia baru dilakukan pada tahun 1990. Majelis Ulama Indonesia (MUI) pada tanggal 1820 Agustus 1990 menyelenggarakan Lokakarya bunga bank dan Perbankan di Cisarua Bogor Jawa Barat. Hasil lokakarya tersenut di bahas lebih mendalam pada Musyawarah Nasional IV MUI yang berlangsung di Hotel Sahid Jaya Jakarta, 22-25 Agustus 1990. Berdasarkan amanat Munas IV MUI, dibentuk kelompok kerja untuk mendirikan bank Islam di Indonesia. Kelompok kerja yang disebut Tim Perbankan MUI, bertugas melakukan pendekatan dan konsultasi dengan semua pihak terkait. ${ }^{7}$

Pada tahun 1992 Bank Muamalat Indonesia (BMI) lahir. Walaupun perkembangannya agak terlambat bila dibandingkan dengan Negara-negara muslim lainnya, perbankan syariah di Indonesia akan terus berkembang. Bila pada periode tahun 1992-1998 hanya ada satu unit bank syariah maka pada tahun 2005 jumlah bank syariah di Indonesia telah bertambah menjadi 20 unit yaitu 3 bank umum syariah dan 17 unit usaha syariah. Sementara itu jumlah Bank Perkreditan Rakyat Syariah (BPRS) hingga akhir tahun 2004 bertambah menjadi 88 buah.

Berdasarkan data Bank Indonesia, prospek perbankan syariah pada tahun 2005 diperkirakan cukup baik. Industri perbankan syariah diprediksi masih akan berkembang dengan tingkat pertumbuhan yang cukup tinggi. Jika pada posisi November 2004 volume usaha perbankan syariah telah mencpi 14,0 triliun rupiah, dengan tingkat pertumbuhan yang terjadi pada tahun 2004 sebesar 88,6\%, volume usaha perbankan syariah di akhir tahun 2005 diperkirakan akan mencapai sekitar 24 triliun rupiah. Dengan volume tersebut diperkirakan perbankan syariah akan mencapai pangsa sebesar $1,8 \%$ dari industri perbankan nasional dibandingkan sebesar $1,1 \%$ pada akhir tahun 2004. Pertumbuhan volume usaha perbankan syariah tersebut ditopang oleh rencana pembukaan unit usaha syariah yang baru dan pembukaan jaringan kantor yang lebih luas. Dana Pihak Ketiaga (DPK) diperkirakan akan mencapai jumlah sekitar 20 triliun rupiah dengan pembiayaan sekitar 21 triliun rupiah di akhir tahun $2005 .^{8}$

\section{Tujuan bank syariah}

Sesuai dengan prinsip-prinsip hukum Islam dan sesuai dengan situasi dan kondisi di Indonesia, maka Bank Syariah ini mempunyai tujuan umum sebagai berikut: 9 2001), 25

7 Muhammad Syafi'i Antonio, Bank Syariah Dari Teori Ke Praktek, (Jakarta : Gema Insani,

8 Adiwarman A. Karim, Bank Islam Analisi Fiqh Dan Keuangan Ed 3, (Jakarta : PT. Raja Grafindo Persada, 2006), 25

9 Mochammad Parmudi, Sejarah dan Doktrin Bank Islam, (Yogyakarta : Kutub, 2005), 61. 
a. Meningkatkan kualitas kehidupan sosial ekonomi masyarakat, sehingga kian berkurang kesenjangan sosial ekonomi, melalui peningkatan kesempatan kerja.

b. Meningkatkan partisipasi masyarakat dalam proses pembangunan bidang ekonomi keuangan, yang selama ini diketahui masih cukup banyak masyarakat yang enggan berhubungan dengan bank karena masih menganggap bahwa bunga bank itu riba.

c. Mengembangkan lembaga bank dan sistem perbankan yang sehat berdasarkan prinsip efisiensi dan keadilan, mampu meningkatkan partisipasi masyarakat sehingga menggalakkan usaha-usaha ekonomi rakyat, antara lain memperluas jaringan lembaga perbankan ke daerah-daerah terpencil.

\section{Prinsip dasar bank syariah}

Adapun prinsip-prinsip bank syariah adalah sebagai berikut:

a. Prinsip titipan atau simpanan (Al- wadi'ah)

Al-wadia'ah dapat diartikan sebagai titipan murni dari satu pihak ke pihak lain, baik individu maupun badan hukum yang harus dijaga dan dikembalikan kapan saja si penitip menghendaki. Secara umum terdapat dua jenis al-wadi'ah, yaitu:

1) Wadi'ah Yad Al-amanah (Trustee Depository) adalah akad penitipan barang /uang dimana pihak penerima titipan tidak diperkenankan dan tidak bertanggung jawab atas kerusakan atau kehilangan barang titipan yang bukan diakibatkan perbuatan atau kelalaian penerima titipan. Adapun aplikasinya dalam perbankan syariah berupa produk safe deposit box.

2) Wadi'ah Yad adh-Dhamanah (Guarantee Depository) adalah akad penitipan barang /uang dimana pihak penerima titipan dengan atau tanpa izin pemilik barang /uang dapat memenfaatkan barang/uang titipan dan harus bertanggung jawab terhadap kehilangan atau kerusakan barang/uang titipan. Semua manfaat dan keuntungan yang diperoleh dalam penggunaan barang/uang titipan menjadi hak penerima titipan. Prinsip ini diaplikasikan dalam produk giro dan tabungan. ${ }^{10}$

b. Prinsip bagi hasil (Profit Sharing)

Secara umum prinsip bagi hasil dalam perbankan syariah dapat dilakukan dalam empat akad utama yaitu al-musyarakah, al-mudharabah, almuzara'ah, dan al-musaqah. Sungguhpun demikian prinsip yang paling banyak dipakai adalah al-musyarakah dan al-mudhrabah, sedangkan al-muzara'ah dan al-musaqah dipergunakan khusus untuk plantation financing atau pembiayaan pertanian oeh beberapa bank Islam.

1) Al- musyarakah (Partnership, Project Financing Participation)

10 Abdul Wadud Nafis, Bank Syari'ah Teori Dan Praktek, (Jakarta : Mitra Abadi Press, 2009), $87-88$ 
Adalah akad kerjasama antara dua pihak atau lebih untuk suatu usaha tertentu di mana masing-masing pihak memberikan kontribusi dana (atau amal/ expertise) dengan kesepakatan bahwa keuntungan dan resiko akan ditanggung bersama sesuai dengan kesepakatan. ${ }^{11}$

Sedangkan aplikasinya dalam perbankan adalah:

a) Pembiayaan proyek

Al-musyarakah biasanya diaplikasian untuk pembiayaan proyek dimana nasabah dan bank sama-sama menyediakan dana untuk membiayai proyek tersebut. Setelah proyek selesai, nasabah mengembalikan dana tersebut bersama bagi hasil yang telah disepakati untuk bank.

b) Modal Ventura

Pada lembaga keuangan khusus diperbolehkan melakukan innvestasi dalam kepemilikan perusahaan, al-musyarakah diterapkan dalam skema modal ventura. Penanaman modal dilakukan untuk jangka waktu tertentu dan setelah itu bank melakukan divestasi atau menjual bagian sahamnya, baik secara singkat maupun bertahap. ${ }^{12}$

2) Al-mudharabah (Trust Financing, Trust Investment)

Al-mudharabah adalah akad kerjasama usaha antara dua pihak dimana pihak pertama (shohibul maal) menyediakan seluruh (100\%) modal, sedangkan pihak lainnya menjadi pengelola. Keuntungan usaha secara mudharabah dibagi menurut kesepakatan yang dituangkan dalam kontrak, sedangkan apabila rugi ditanggung oleh pemilik modal selama kerugian itu bukan akibat kelalaian si pengelola. Seandainya kerugian itu diakibatkan karena kecurangan ata kelalaian si pengelola, si pengelola harus bertanggung jawab atas kerugian tersebut.

Sedangkan aplikasi dalam perbankan sebagai berikut:

Al-mudharabah biasanya diterapkan dalam produk-produk pembiayaan dan pendanaan. Pada sisi penghimpunan dana, al-mudharabah diterapkan pada:

a) Tabungan berjangka, yaitu tabungan yang dimaksudkan untuk tujuan khusus, seperti tabungan haji tabungan kurban dan sebagainya.

b) Deposito special (special investment), dimana dana yang dititipkan nasabah khusus untuk bisnis tertentu misalnya murabahah saja atau ijarah saja.

Adapun pada sisi pembiayaan, mudharabah diterapkan untuk:

a) Pembiayaan modal kerja, seperti modal kerja perdagangan dan jasa.

b) Investasi khusus disebut juga mdharabah muayyadah, dimana sumber dana khusus dengan penyaluran yang khusus dengan syarat-syarat yang telah ditetaokan oleh shohibul maal.

11 Muhammad Syafi'I Antonio, Bank Syariah Dari Teori Dan Praktek, (Jakarta : Gema Insani, 2001), 90-91

12 Ibid, 93 


\section{3) Al-muzara'ah ( Harvest-Yield Profit Sharing)}

Al-muzara'ah adalah kerjasama pengolahan pertanian antara pemilik lahan dan penggarap, dimana pemilik lahan memberikan lahan pertanian kepada si penggarap untuk ditanami dan dipelihara dengan imbalan bagian tertentu (presentase) dari hasil panen.

4) Al-musaqah (Plantation Management Fee Based On Certain Portion Of Yield)

Al-musaqah adalah bentuk yang lebih sederhana dari muzara'ah dimana si penggarap hanya bertanggung jawab atas penyiraman dan pemeliharaan. Sebagai imbalan, si penggarap berhak atas nisbah tertentu dari hasil panen13

\section{c. Prinsip jual beli}

Prinsip ini merupakan suatu sistem yang menerapkan tata cara jual beli, dimana bank akan membeli terlebih dahulu barang yang dibutuhkan atau mengangkat nasabah sebagai agen bank melakukan pembelian barang atas nama bank, kemudian bank menjual barang tersebut kepada nasabah dengan harga sejumlahharga beli ditambah keuntungan (margin). Implikasinya berupa:

1) Al-murabahah adalah akad jual beli barang dengan menyatakan harga perolehan dan keutungan (margin) yang diseakati oleh penjual dan pembeli.

2) Salam, adalah akad jual beli barang pesanan dengan penangguhan pengiriman oleh penjual dan pelunasannya dilakukan segera oleh pembeli sebelum barang pesanan tersebut diterima sesuai syarat-syarat tertentu. Bank dapat bertindak sebagai pembeli atau penjual dalam suatu transaksi salam. Jika bank bertindak sebagai penjual kemudian memesan kepada pihak lain untuk menyediakan barang pesanan dengan cara salam maka hal ini disebut salam paralel.

3) Istishna', adalahakad jual beli antara pembeli dan produsen yang juga bertindak sebagai penjual. Cara pembayarannya dapatberupa pembayaran dimuka, cicilan, atau ditangguhkan sampai jangka waktu tertentu. Barang pesanan harus diketahui karateristiknya secara umum yang meliputi: jenis, spesifikasi teknis, kualitas dan kuantiasnya. Bank dapat bertindak sebagai pembeli atau penjual. Jika bank bertindak sebagai penjual kemudian memesan kepada pihak lain untuk menyediakan barang dengan cara istishna' maka hal ini disebut istishna' paralel.

d. Prinsip sewa (Al-ijarah) adalah akad pemindahan hak guna atas barang atau jasa, melalui pembayaran upah sewa, tanpa diikuti dengan pemindahan hak kepemilikan atas barang itu sendiri. Al-ijarah terbagi kepada dua jenis:

\footnotetext{
13 Ibid, 95-100
} 
1) Ijarah sewa murni

2) Ijarah al-muntahiya bi tamlik meruakan penggabungan hak untuk memiliki barang pada akhir masa sewa.

e. Prinsip jasa (Fee-Based Service), Prinsip ini meliputi seluruh layanan non pembiayaan yang diberikan bank. Bentuk produk yang berdasarkan prinsip ini antara lain:

1) Al wakalah

Nasabah memberi kuasa kepada bank untuk mewakili dirinya melakukan pekerjaan jasa tertentu, seperti transfer.

2) Al-kafalah adalah jaminan yang diberikan oleh penanggung kepada pihak ketiga untuk memenuhi kewajiban pihak kedua atau yang ditanggung.

3) Al-hawalah adalah pengalihan hutang dari orang yang berutang kepada orang lain yang wajib menanggungnya. Kontrak hawalah dalam perbankan biasanya diterapkan pada Factoring (anjak piutang), Post dated check, dimana bank bertindak sebagai juru tagih tanpa membayarkan dulu piutangtersebut.

4) Ar-rahn adalah menahan salah satu harta milik si peminjam sebagai jaminan atas pinjaman yang diterimanya. Barang yang ditahan tersebut memiliki nilai ekonomis. Dengan demikian pihak yang menahan memperoleh jaminan untuk dapat mengambil kembali seluruh atau sebagian piutangnya. Secara sederhana dapatdijelaskan bahwa rahn adalah swemacam jaminan utang atau gadai.

5) Al-qardh adalah pemberian harta kepada oranglain yang dapat ditagih atau diminta kembali dengan kata lain meminjamkan tanpa mengharapkan imbalan. Produk ini digunakan untuk membantu usaha kecil dan keperluan sosial. Dana ini diperoleh dari dana zakat, infaq dan shadaqah. $^{14}$

\section{Produk-produk bank syariah dan bank pada umumnya}

Berikut ini dispesifikasikan produk-produk bank syariah dan bank pada umumnya:

a. Produk syariah

1) Jual beli

a) Murabahah yaitu jual beli yang keuntungannya disepakati penjual dan pembeli.

b) Musawamah yaitu jual beli yang keuntungannya hanya diketahui penjual.

14 Zainul Arifin, Dasar-dasar Manajemen Bank Syariah, (Jakarta : Alvabet, 2003), 19-3 dan Abdul Wadud Nafis, Bank Syari'ah Teori Dan Praktek, (Jakarta : Mitra Abadi Press, 2009), 89- 92 
c) Tauliah yaitu jual bei yang tidak ada keuntungan bagi penjual (komisi).

d) Muwadhaah yaitu jual beli yang harganya dibawah harga jual (diskon).

e) Mutlaq yaitu tukar-menukar uang dengan barang.

f) Muqayyadhah yaitu tukar menukar barang dengan barang.

g) Sarf yaitu tukar menukar uang dengan uang.

h) Salam yaitu jual beli yang hanya dibayar lebih dulu, barang diserahkan kemudian.

i) Istisna' yaitu jual beli yang harga dapat dicicil, barang dibuat dan diserahkan kemudian.

j) Wafa yaitu jual beli yang diiringi syarat untuk dibeli kembali.

k) Urbun yaitu jual beli yang jika tidak diteruskan uang muka jadi milik penjual.

2) Bagi untung/ bagi hasil

a) Mudharabah yaitu perkongsian pemodal (shohibul maal) dan pengelola (mudharib), keuntungan dibagi menurut porsi yang disepakati sebelumnya, sedangkan jika usaha rugi ditanggung pemodal.

b) Musyarakah yaitu perkongsian para pemodal, keuntungan dibagi menurut porsi yang disepakati sebelumnya, kerugian ditanggung bersama berdasarkan proporsi modal.

c) Muzara'ah yaitu perkongsian pemilik tanah pertanian dan pengelola, pembagian hasil menurut porsi yang disepakati sebelumnya.

d) Musaqat yaitu perkongsian pemilik tanah perkebunan dan pengelola, pembagian menurut porsi yang disepakati sebelumnya.

b. Produk perbankan

1) Pembiayaan

a) Kredit investasi

b) Kredit modal kerja

c) Kredit konstruksi

2) Pembangunan

a) Kredit usaha kecil

b) Kredit usaha tani

c) Kredit usaha koperasi

3) Konsumsi

a) Kredit pemilikan rumah

b) Kredit pemilikan kendaraan

4) Kredit eksport

a) Letter of credit

b) Garansi

5) Bank treasury 

a) Spot
b) Forward
c) Swap
d) Option $^{15}$

\section{Karakteristik bank syariah ${ }^{16}$}

Dalam menjalankan aktivitasnya bank syariah menganut prinsip-prinsip sebagai berikut.

a. Prinsip Keadilan

Dengan sistem operasional yang berdasarkan "profit and loss sharing system", bank syariah memiliki kekuatan tersendiri yang berbeda dari sistem konvensional. Bank konvensional dengan sistem bunga memandang dan memberlakukan bahwa kekayaan yang dimiliki peminjam menjadi jaminan atas pinjamannya. Apabila terjadi kerugian pada proyek yang didanai maka peminjam modal akan disita menjadi hak milik pemodal (bank). Sedangkan dalam bank syariah kelayakan usaha atau proyek yang akan didanai itu menjadi jaminannya apakah untung atau rugi, sehingga keuntungan dan kerugiannya menjadi tanggungan bersama.

b. Prinsip Kesederajatan

Bank syariah menempatkan nasabah penyimpan dana, nasabah pengguna dana, maupun Bank pada kedudukan yang sama dan sederajat. Hal ini dapat dilihat dalam hak, kewajiban, risiko dan keuntungan yang berimbang antara nasabah penyimpan dana, nasabah pengguna dana maupun Bank.

c. Prinsip ketentraman

Menurut falsafah al-Qur'an, semua aktifitas yang dilakukan oleh manusia patut dikerjakan untuk mendapatkan falah (ketentraman, kesejahteraan, dan kebahagiaan).

\section{Perbandingan antara bank syariah dengan bank konvensional}

Perbandingan antara Bank Syariah dan Bank Konvensional disajikan dalam tabel berikut ini. ${ }^{17}$

\begin{tabular}{|l|l|}
\hline BANK ISLAM & BANK KONVENSIONAL \\
\hline
\end{tabular}

15 Khaerul Umam, Manajemen Perbankan Syariah, (Bandung : Pustaka Setia, 2013), 37

16 Muhammad, Bank Syariah Problem dan Prospek Perkembangan di Indonesia, (Yogyakarta : Graha Ilmu, 2005), 78.

17 Muhammad Syafi'i Antonio, Bank Syariah dari Teori ke Praktik, (Jakarta : Gema Insani, 2001), 34 


\begin{tabular}{|l|l|}
\hline $\begin{array}{l}\text { 1. Melakukan investasi yang halal } \\
\text { - halal saja. }\end{array}$ & $\begin{array}{l}\text { 1. Investasi yang halal dan haram. } \\
\text { 2. Memakai perangkat bunga. }\end{array}$ \\
$\begin{array}{l}\text { 2. Berdasarkan prinsip bagi hasil, } \\
\text { jual beli atau sewa. }\end{array}$ & $\begin{array}{l}\text { 3. Profit oriented. } \\
\text { 4. Hubungan dengan nasabah } \\
\text { dalam dalam bentuk hubungan } \\
\text { 3. Profit dan falah oriented. }\end{array}$ \\
$\begin{array}{l}\text { 4. Hubungan dengan nasabah } \\
\text { dalam bentuk kemitraan. }\end{array}$ & 5. Tidak terdapat dewan sejenis. \\
5. Penghimpunan dan penyaluran \\
$\begin{array}{l}\text { dana harus sesuai dengan fatwa } \\
\text { DPS. }\end{array}$
\end{tabular}

\section{Perkembangan perbankan syariah di Indonesia}

Sebaran jaringan Kantor BUS dan UUS di Indonesia sebagai berikut:

\begin{tabular}{|c|c|c|c|c|}
\hline $\mathrm{NO}$ & Kelompok Bank & $\frac{\mathrm{KPO} / \mathrm{KC}}{\mathrm{HOO} / \mathrm{BO}}$ & $\frac{\text { KCP/UPS }}{\text { SBO/SSU }}$ & $\frac{\mathrm{KK}}{\mathrm{CO}}$ \\
\hline & Bank Umum Syariah & 474 & 1.207 & 192 \\
\hline 1 & Jawa Barat & 61 & 225 & 28 \\
\hline 2 & Banten & 19 & 66 & 8 \\
\hline 3 & DKI Jakarta & 74 & 157 & 38 \\
\hline 4 & Yogyakarta & 9 & 24 & 13 \\
\hline 5 & Jawa Tengah & 40 & 90 & 20 \\
\hline 6 & Jawa Timur & 43 & 134 & 18 \\
\hline 7 & Bengkulu & 5 & 12 & - \\
\hline 8 & Jambi & 7 & 18 & 1 \\
\hline 9 & Nangroe Aceh Darussalam & 37 & 102 & 19 \\
\hline 10 & Sumatera Utara & 25 & 50 & 5 \\
\hline 11 & Sumatera Barat & 10 & 3 & 4 \\
\hline 12 & Riau & 11 & 31 & 8 \\
\hline 13 & Sumatera Selatan & 15 & 35 & 1 \\
\hline 14 & Bangka Belitung & 3 & 8 & - \\
\hline 15 & Kepulauan Riau & 6 & 16 & 3 \\
\hline 16 & Lampung & 10 & 31 & 2 \\
\hline 17 & Kalimantan Selatan & 9 & 19 & 5 \\
\hline 18 & Kalimantan Barat & 9 & 13 & 1 \\
\hline 19 & Kalimantan Timur & 14 & 33 & 4 \\
\hline 20 & Kalimantan Tengah & 6 & 6 & - \\
\hline 21 & Sulawesi Tengah & 6 & 10 & - \\
\hline 22 & Sulawesi Selatan & 12 & 33 & 9 \\
\hline 23 & Sulawesi Utara & 4 & 4 & - \\
\hline 24 & Gorontalo & 2 & 3 & 1 \\
\hline 25 & Sulawesi Barat & 2 & 1 & - \\
\hline
\end{tabular}




\begin{tabular}{|l|l|c|c|c|}
\hline 26 & Sulawesi Tenggara & 7 & 9 & 2 \\
\hline 27 & NTB & 8 & 19 & 2 \\
\hline 28 & Bali & 7 & 11 & - \\
\hline 29 & NTT & 3 & 1 & - \\
\hline 30 & Maluku & 2 & 3 & - \\
\hline 31 & Papua & 2 & 5 & - \\
\hline 32 & Maluku Utara & 3 & 4 & - \\
\hline 33 & Papua Barat & 2 & 2 & - \\
\hline 34 & Luar Indonesia & 1 & - & - \\
\hline
\end{tabular}

\begin{tabular}{|c|l|c|c|c|}
\hline NO & Kelompok Bank & $\underline{\mathrm{KPO} / \mathrm{KC}}$ & $\underline{\mathrm{KCP} / \mathrm{HOS}}$ & $\underline{\mathrm{KK}}$ \\
\hline & Unit Usaha Syariah & $\mathbf{1 4 9}$ & $\mathbf{1 3 5}$ & $\mathbf{4 8}$ \\
\hline 1 & Jawa Barat & 19 & 14 & 7 \\
\hline 2 & Banten & 3 & 7 & - \\
\hline 3 & DKI Jakarta & 10 & 16 & 7 \\
\hline 4 & Yogyakarta & 18 & 11 & 5 \\
\hline 5 & Jawa Tengah & 23 & 16 & 4 \\
\hline 6 & Jawa Timur & 1 & - & - \\
\hline 7 & Bengkulu & 2 & - & - \\
\hline 8 & Jambi & 4 & - & - \\
\hline 9 & Nangroe Aceh Darussalam & 12 & 17 & - \\
\hline 10 & Sumatera Utara & 4 & 6 & - \\
\hline 11 & Sumatera Barat & 3 & 3 & 3 \\
\hline 12 & Riau & 6 & 2 & 4 \\
\hline 13 & Sumatera Selatan & - & 1 & - \\
\hline 14 & Bangka Belitung & 4 & 3 & - \\
\hline 15 & Kepulauan Riau & 1 & - & - \\
\hline 16 & Lampung & 7 & 9 & 1 \\
\hline 17 & Kalimantan Selatan & 4 & 4 & 5 \\
\hline 18 & Kalimantan Barat & 6 & 13 & 3 \\
\hline 19 & Kalimantan Timur & - & - & - \\
\hline 20 & Kalimantan Tengah & - & - & - \\
\hline 21 & Sulawesi Tengah & 9 & 1 & 1 \\
\hline 22 & Sulawesi Selatan & - & - & - \\
\hline 23 & Sulawesi Utara & - & - & - \\
\hline 24 & Gorontalo & - & - & - \\
\hline 25 & Sulawesi Barat & - & - & - \\
\hline 26 & Sulawesi Tenggara & - & 1 & 1 \\
\hline 27 & NTB & - \\
\hline 28 & Bali & & \\
\hline & & - & & - \\
\hline
\end{tabular}




\begin{tabular}{|c|l|c|c|c|}
\hline 29 & NTT & - & - & - \\
\hline 30 & Maluku & - & - & - \\
\hline 31 & Papua & - & - & - \\
\hline 32 & Maluku Utara & - & - & - \\
\hline 33 & Papua Barat & - & - & - \\
\hline 34 & Luar Indonesia & - & - & - \\
\hline \multicolumn{2}{|l|}{ Total BUS dan UUS } & $\mathbf{6 2 3}$ & $\mathbf{1 . 3 4 2}$ & $\mathbf{2 4 0}$ \\
\hline
\end{tabular}

Sumber: SPS Jan 2017

Keterangan:

KP: Kantor Pusat

UUS: Unit Usaha Syariah

KPO: Kantor Pusat Operasional

KC: Kantor Cabang

KCP/UPS: Kantor Cabang Pembantu/Unit Pelayanan Syariah

KK: Kantor Kas

Melihat perkembangan perbankan syariah yang ada di Indonesia bisa dikatakan cukup pesat, hal ini terbukti dengan cukup cepatnya perbankan syariah menyebar ke berbagai provinsi di Indonesia, bahkan tiap provinsi di Indonesia bisa dikatakan memiliki bank syariah. Dari tahun 1992 sampai 2017 yaitu sekitar 25 tahun munculnya di Indonesia kini bank syariah dari kategori BUS (Bank Umum Syariah) sudah memiliki 474 KPO/KC ( Kantor Pusat Operasional/ Kantor Cabang) dan memiliki 1.207 Kantor Cabang Pembantu (KCP) serta memiliki 192 Kantor Kas (KK). Sedangkan Unit Usaha Syariah hingga saat ini sudah memiliki $149 \mathrm{KPO} / \mathrm{KC}$, $135 \mathrm{KCP}$, dan $48 \mathrm{KK}$ yang tersebar diseluruh Indonesia. Hingga saat ini total BUS dan UUS di Indonesia untuk KPO/KC berjumlah 623, KCP/UPS sejumlah 1.342 sedangkan KK sejumlah 240. Hal ini menunjukkan bahwa bank syariah sudah bisa memasuki pasarnya dan sudah bisa dikenali oleh seluruh masyarakat Indonesia dengan tersebarnya bank syariah di seluruh provinsi. Bukan hanya itu banyaknya bank yang awalnya berbasis konvensional kini sudah banyak yang membuka unitunit yang berbasis syariah, ini menunjukkan bahwa masyarakat sudah mulai terbiasa dan tertarik untuk berkecipung dalam bank yang berbasis syariah. Guna memenuhi permintaan tersebut akhirnya banyaklah bank yang awalnya berbasis konvensional sekarang sudah mulai membuka unit yang berbasis syariah.

Jumlah BPRS berdasarkan lokasi :

\begin{tabular}{|c|l|c|c|c|c|c|}
\hline No & \multicolumn{1}{|c|}{ Propinsi } & $\mathbf{2 0 1 2}$ & $\mathbf{2 0 1 3}$ & $\mathbf{2 0 1 4}$ & $\mathbf{2 0 1 5}$ & $\mathbf{2 0 1 6}$ \\
\hline 1 & Jawa Barat & 27 & 28 & 28 & 28 & 28 \\
\hline 2 & Banten & 8 & 8 & 8 & 8 & 8 \\
\hline 3 & DKI Jakarta & 2 & 2 & 2 & 1 & 1 \\
\hline 4 & DIY & 11 & 11 & 11 & 11 & 12 \\
\hline 5 & Jawa Tengah & 24 & 25 & 25 & 26 & 26 \\
\hline
\end{tabular}




\begin{tabular}{|c|l|c|c|c|c|c|}
\hline 6 & Jawa Timur & 31 & 31 & 31 & 29 & 29 \\
\hline 7 & Bengkulu & 2 & 2 & 2 & 2 & 2 \\
\hline 8 & Jambi & - & - & - & - & - \\
\hline 9 & Nangroe Aceh & 10 & 10 & 10 & 10 & 10 \\
\hline 10 & Sumatera Utara & 8 & 8 & 8 & 8 & 8 \\
\hline 11 & Sumatera Barat & 7 & 7 & 7 & 7 & 7 \\
\hline 12 & Riau & 2 & 2 & 2 & 3 & 3 \\
\hline 13 & Sumatera Selatan & 1 & 1 & 1 & 1 & 1 \\
\hline 14 & Kepualauan Bangka & 1 & 1 & 1 & 1 & 1 \\
\hline 15 & Belitung & & & & & \\
\hline 16 & Kepulauan Riau & 2 & 2 & 1 & 1 & 1 \\
\hline 17 & Kalsel & 7 & 8 & 8 & 10 & 11 \\
\hline 18 & Kalbar & 1 & 1 & 1 & 1 & 1 \\
\hline 19 & Kaltim & - & - & - & - & - \\
\hline 20 & Kalteng & 1 & 1 & 1 & 1 & 1 \\
\hline 21 & Sulteng & - & 1 & 1 & 1 & 1 \\
\hline 22 & Sulsel & - & - & - & - & - \\
\hline 23 & Sulut & 7 & 8 & 8 & 8 & 8 \\
\hline 24 & Gorontalo & - & - & - & - & - \\
\hline 25 & Sulbar & - & - & - & - & - \\
\hline 26 & Sul Tenggara & - & - & - & - & - \\
\hline 27 & NTB & - & - & - & - & - \\
\hline 28 & Bali & 1 & 1 & 1 & 1 & 1 \\
\hline 29 & NTT & - & - & - & - & - \\
\hline 30 & Maluku & $\mathbf{1 5 8 3}$ & $\mathbf{1 6 3}$ & $\mathbf{1 6 3}$ & $\mathbf{1 6 6}$ \\
\hline 31 & Papua & & & & \\
\hline 32 & Irian Jaya Barat & - & 1 & 1 & 1 \\
\hline 33 & Maluku Utara & - & - & - & - \\
\hline Total & & - & - & - & - & - \\
\hline
\end{tabular}

Sumber: SPS Jan 2107

Bukan hanya BUS dan UUS yang mengalami perkembangan yang pesat, Bank Perkreditan Rakyat Syariah pun demikian, dari tahun 2012 sampai 2016 jumlah BPRS semakin meningkat. Hal ini bisa dilihat dalam table diatas bahwa dari tahun ke tahun jumlah BPRS di provinsi yang ada di Indonesia mengalami penambahan jumlah. Di tahun 2012 contohnya BPRS berjumlah 158 dan langsungnaik di tahun 2016 menjadi 166. Yang menjadi masalah dalam menjalankan sebuah usaha apapun baik itu lembaga keuangan syariah adalah bagaimana cara mempertahankan prestasi yang sudah di raih. Dan BPRS sudah bisa dikatakan mampu mempertahankan prestasinya lebih lagi bisa menambah jumlah 
kantor maupun operasionalnya dari tahun ke tahun. Hal ini menunjukkan bahwa BPRS tetap eksis dalam melayani masyarakat secara luas. 
Jumlah Nasabah Pembiayaan, DPK BUS dan UUS

\begin{tabular}{|c|l|l|l|l|}
\hline No & \multicolumn{1}{|c|}{ Tipe } & \multicolumn{1}{|c|}{$\mathbf{2 0 1 4}$} & \multicolumn{1}{c|}{$\mathbf{2 0 1 5}$} & \multicolumn{1}{c|}{$\mathbf{2 0 1 6}$} \\
\hline 1 & DPK & 11.444 .013 & 14.761 .002 & 18.521 .091 \\
\hline 2 & $\begin{array}{l}\text { Pembiayaan, Piutang dan } \\
\text { Salam }\end{array}$ & 3.175 .910 & 3.401 .887 & 3.801 .121 \\
\hline
\end{tabular}

Sumber referensi: SPS Jan 2017

Mengenai jumlah nasabah yang mengambil pembiayaan atau jika dalam perbankan dikenal DPK (Dana Pihak Ketiga) dari tahun 2014 sampai 2016 DPK semakin meningkatyaitu tahun 2014 sebesar 11.444.013 dan meningkat di tahun 2016 menjadi 18.521.091. Begitu juga untuk pembiayaan, piutang, dan salam juga mengalami kenaikan. Di tahun 2014 berkisar sebesar 3.175.910 dan di tahun 2016 meningkat menjadi 3.801.121. Semakin banyaknya DPK, menunjukkan bahwa banyaknya masyarakat yang mulai percaya kepada bank syariah baik dalam menyimpan uangnya maupun pengambilan pembiyaan yang ditawarkan bank syariah yang bertujuan untuk memperbaiki perekonomian masyarakat. Karena fungsi utama dari adanya perbankan adalah untuk memediasi orang yang surplus terhadap orang yang defisit dana sehingga orang yang mengalami defisit bisa tetap menjalankan usahanya yang dibantu oeh orang yang surplus dana dan mediatornya adalah perbankan.

Jumlah Rekening Pembiayaan dan Dana Pihak Ketiga BUS dan UUS sebagai berikut:

\begin{tabular}{|l|l|l|l|l|}
\hline No. & \multicolumn{1}{|c|}{ Tipe } & \multicolumn{1}{c|}{$\mathbf{2 0 1 4}$} & \multicolumn{1}{c|}{$\mathbf{2 0 1 5}$} & \multicolumn{1}{c|}{2016} \\
\hline & Dana Pihak Ketiga & 14.386 .575 & $\mathbf{1 8 . 4 8 1 . 9 1 1}$ & $\mathbf{2 2 . 1 9 8 . 7 1 8}$ \\
\hline 1. & Dana simpanan wadiah & 7.839 .979 & $\mathbf{9 . 1 2 7 . 2 5 3}$ & $\mathbf{1 2 . 2 6 6 . 6 5 6}$ \\
\hline & Giro & 142.557 & $\mathbf{1 6 9 . 8 0 1}$ & $\mathbf{2 3 5 . 8 6 2}$ \\
\hline & Tabungan & 7.697 .421 & $\mathbf{8 . 9 5 7 . 4 5 2}$ & $\mathbf{1 2 . 0 3 0 . 7 9 4}$ \\
\hline 2. & $\begin{array}{l}\text { Dana Investasi Non Profit } \\
\text { Sharing }\end{array}$ & 6.537 .113 & $\mathbf{9 . 3 4 6 . 1 4 9}$ & $\mathbf{9 . 9 3 2 . 0 6 2}$ \\
\hline & Giro & 6.491 & $\mathbf{9 . 3 8 4}$ & $\mathbf{6 4 . 7 7 6}$ \\
\hline & Tabungan & $\mathbf{6 . 2 6 3 . 9 1 2}$ & $\mathbf{9 . 0 4 4 . 7 4 9}$ & $\mathbf{9 . 5 5 5 . 9 1 1}$ \\
\hline & Deposito & $\mathbf{2 6 6 . 7 1 0}$ & $\mathbf{2 9 2 . 0 1 6}$ & $\mathbf{3 1 1 . 3 7 5}$ \\
\hline 3. & Dana Investasi Profit Sharing & $\mathbf{9 . 4 8 4}$ & $\mathbf{8 . 5 0 9}$ & - \\
\hline & Giro & $\mathbf{2}$ & $\mathbf{2}$ & - \\
\hline & Tabungan & $\mathbf{8 . 7 3 7}$ & $\mathbf{7 . 7 9 4}$ & - \\
\hline & Deposito & $\mathbf{7 4 5}$ & $\mathbf{7 1 3}$ & - \\
\hline & $\begin{array}{l}\text { Pembiayaan, Piutang dan } \\
\text { Salam }\end{array}$ & $\mathbf{3 . 7 6 9 . 1 8 1}$ & $\mathbf{3 . 7 4 6 . 5 6 5}$ & $\mathbf{4 . 5 1 5 . 9 3 0}$ \\
\hline 1. & Pembiayaan bagi hasil & $\mathbf{1 1 9 . 5 9 2}$ & $\mathbf{9 6 . 2 8 4}$ & $\mathbf{9 7 . 2 9 9}$ \\
\hline & Mudharabah & $\mathbf{4 7 . 1 9 1}$ & $\mathbf{4 0 . 0 1 1}$ & $\mathbf{3 5 . 9 4 8}$ \\
\hline & Musyarakah & $\mathbf{5 5 . 8 6 8}$ & $\mathbf{5 6 . 2 7 3}$ & $\mathbf{6 1 . 3 5 1}$ \\
\hline
\end{tabular}




\begin{tabular}{|l|l|l|l|l|}
\hline & Pembiayaan bagi hasil lainnya & $\mathbf{1 6 . 5 3 3}$ & - & - \\
\hline 2. & Piutang & $\mathbf{3 . 5 7 6 . 8 6 3}$ & $\mathbf{3 . 5 9 2 . 7 3 7}$ & $\mathbf{4 . 3 8 2 . 8 6 5}$ \\
\hline & Murabahah & $\mathbf{3 . 2 3 0 . 4 9 0}$ & $\mathbf{3 . 3 3 4 . 4 1 7}$ & $\mathbf{4 . 0 9 6 . 4 5 9}$ \\
\hline & Qardh & $\mathbf{3 4 3 . 4 0 2}$ & $\mathbf{2 5 4 . 7 9 6}$ & $\mathbf{2 8 2 . 2 5 3}$ \\
\hline & Istisna' & $\mathbf{2 . 9 7 1}$ & $\mathbf{3 . 5 2 4}$ & $\mathbf{4 . 1 5 3}$ \\
\hline 3. & Pembiayaan sewa (ijarah) & $\mathbf{7 2 . 7 2 6}$ & $\mathbf{5 7 . 5 4 4}$ & $\mathbf{3 5 . 7 6 6}$ \\
\hline & Pembiayaan sindikasi & $\mathbf{3}$ & $\mathbf{3}$ & - \\
\hline & Pembiayaan secara Channeling & $\mathbf{1 . 4 4 3}$ & $\mathbf{2 2 2}$ & $\mathbf{2 0 8}$ \\
\hline & Pembiayaan secara Executing & - & - & - \\
\hline & Pembiayaan sewa lainnya & $\mathbf{7 1 . 2 8 0}$ & $\mathbf{5 7 . 3 1 9}$ & $\mathbf{3 5 . 5 5 8}$ \\
\hline 4. & Salam & - & - & - \\
\hline
\end{tabular}

Sumber: SPS Jan 2017

DPK dari tahun 2014 sampai 2016 mengalami peningkatan yang cukup baik yaitu dari 14.386.575 menjadi 22.198.718. Dan pada tahun 2016 untuk dana investasi profit sharing tidak ada, namun lebih fokus pada dana simpanan wadi'ah dan dana investasi non profit sharing yang terlihat mengalami kenaikan dari tahun ke tahun. Sedangkan untuk pembiayaan, piutang dan salam juga mengalami kenaikan dari tahun 2014 sampai 2016 yaitu 3.769.181 menjadi 4.515.930. Adapun pembiayaan yang dijalankan adalah bagi hasil (mudhrabah, musyarakah dan pembiayaan bagi hasil lainnya). Untuk pembiayaan mudharabah mengalami sedikit penurunan, yaitu di tahun 2014 sebesar 47.191 dan 2016 sebesar 35.948. Beda halnya denga musyarakah justru mengalami kenaikan yaitu 2014 sebesar 55.868 menjadi 61.351, dan untuk pembiyaan bagi hasil lainnya mulai 2015 perbankan syariah memang tidak menjalankan pembiyaan bagi hasil selain mudharabah dan musyarakah. Untuk piutang mengalami kenaikan dari tahun 2014 ke 2016 yaitu dari 3.576.863 ke 4.382.865. Piutang ini meliputi murabahah, qard, istisna'. Untuk murabahah, qard dan istisna' semua mengalami kenaikan (bisa lihat ditabel diatas). Sedangkan untuk pembiayaan sewa mengalami penurunan. Sedangkan salam dari tahun 2014 sampai 2016 memang tidak dijalankan. Walaupun ada fluktuasi dalam perkembangan masing-masing dana simpanan wadi'ah, investasi non profit sharing dan lain-lain serta naik turunnya pembiayaan bagi hasil mudharabah, musyarakah dan lainnya serta piutang murabahah, qard dan istisna', namun secara keseluruhan dari DPK dan Pembiayaan, piutang dan salam mengalami kenaikan.

\section{Kesimpulan}

Bank Islam merupakan lembaga keuangan yang dalam operasionalnya tidak menggunakan sistem bunga, dan dikenal denga perbankan syariah. Dari awal munculnya di Indonesia tahun 1992 haingga saat ini perbankan syariah bisa dikatakan mengalami pertumbuhan atau perkembangan yang pesat. Hal ini dibuktikan dengan tersebarnya perbankan syariah diseluruh provinsi, kabupaten di seluruh Indonesia. Keberadaan bank syariah bukan hal yang asing lagi bagi masyarakat baik diperkotaan maupun pedesaan, karena pertahanan dan 
perkembangan bank syariah yang baik ini maka bank syariah bisa dikatakan bank yang bisa tetap eksis dari awal berdiri hingga saat ini bahkan dengan perkembangan yang baik. Dengan sistem bagi hasil yang ditawarkannya kepada masyarakat, mampu membuat masyarkat terlepas dari sistem bunga yang memang sudah dikenal terlebih dahulu oleh masyarakat Indonesia. Namun saat ini masyarakat tidak perlu gelisah dengan beban bunga yang akan dikenakan jika mengambil pembiayaan kepada perbankan karena perbankan syariah sudah menghapus sistem bunga dan mengganti dengan sistem bagi hasil yang jika mengalami keuntungan dirasakan/ditanggung bersama oleh bank dan nasabah begitu juga apabila mengalami kerugian. Ini merupakan solusi dari sistem perbankan di Indonesia yang tidak memberatkan dan lebih mengayomi kepada masyarakat dan tujuan dari perbankan syariah dengan sistem yang dibawanya adalah untuk membantu masyarakat dari belenggu kemiskinan. Oleh karena perbankan syariah banyak diminati oleh masyarakat dan tetap eksis hingga saat ini. Hal ini bisa dibuktikan dengan terus meningkatkan DPK (Dana Pihak Ketiga) maupun pembiyaan yang ada di perbankan syariah, ini berarti masyarakat sudah tidak ragu lagi untuk berhubungan dengan bank syariah dan sudah terbiasa dan mulai mengenal dan mempercayakan keuangannya kepada bank syariah. Untuk simpanan yang terus meningkat ini menandakan bahwa banyak masyarakat yang mempercayakan uangnya untuk disimpan di bank syariah yang dikenal amanah. Untuk pembiyaan yang dari tahun ke tahun semakin meningkat, ini menunjukkan bahwa bank syariah telah menjalankan fungsi utamanya dengan baik yaitu sebagai mediator bagi orang yang surplus dana terhadap orang yang defisit dana. Orang yang surplus dana bisa menyalurkan dananya kepada orang yang deficit dana melalui perbankan dengan sistem-sistem yang tidak merugikan kedua belah pihak. 


\section{Daftar Pustaka}

Abdul Wadud Nafis, Bank Syari'ah Teori Dan Praktek, 2009, Jakarta: Mitra Abadi Press

Amir, Machmud \& Rukmana, Bank Syariah, 2010, Jakarta: Erlangga

Arifin, Zainul, Dasar-dasar Manajemen Bank Syariah, 2003, Jakarta:Alvabet

Azwar Karim, Adiwarman, Bank Islam Analisi Fiqh Dan Keuangan Ed 3, 2006, Jakarta: PT. Raja Grafindo Persada

Ismail, Perbankan Syariah, 2011, Jakarta: Kencana-Prenada Media Group

Muhammad, Bank Syariah Problem dan Prospek perkembangan di Indonesia, 2005, Yogyakarta: Graha Ilmu

Muhammad, Manajemen Bank Syariah, 2002, Yogyakarta: UPP AMP YKPN

Nazir, Muhammad, Metode Penelitian, cet, ke 5, 2003, Jakarta: Ghalia Indonesia

Parmudi, Mochammad, Sejarah dan Doktrin Bank Islam, 2005, Yogyakarta: Kutub

Syafi' i Antonio, Muhammad, Bank Syariah dari Teori ke Praktik, 2001, Jakarta : Gema Insani

Umam, Khaerul, Manajemen Perbankan Syariah, 2013, Bandung: Pustaka Setia 